\title{
Leprosy in Kenya, Zanzibar and Tanganyika.
}

\author{
R. G. Cochrane.
}

$\mathrm{O}$ WING to the publication of the special Leonard Wood Memorial Conference number this series of articles on leprosy in British Africa had to be postponed. I propose to deal in this contribution with leprosy in Kenya, Zanzibar and Tanganyika, and I shall conclude this series in the next number of the Review by a summary of the situation in S. Rhodesia and South Africa.

KENYA.

Kenya, with a population of $2,736,517$ (1926) and an area of 225,100 square miles, can be divided into three main areas as far as leprosy is concerned, viz., North and Central Kavirondo; (2) Coastal Region; (3) Frontier Province. The former two foci are known to exist and the latter is suggested for it is reported by those who have been stationed in that most inaccessible part of Kenya that leprosy is fairly prevalent, and in Abyssinia it is known to be widespread. It is not suggested that leprosy is not prevalent in other areas of Kenya, for instance, there appears to be quite a definite focus in the Kikuyu territory, and Dr. Irvine of the Scottish Mission has an extensive work at Chogoria. It seems, however, that the areas already mentioned are those of the heaviest incidence. I shall deal mainly then with the situation in North and Central Kavirondo and the Coastal Area.

(1) North and Central Kavirondo.

In North Kavirondo there is a leprosy settlement at Kakamega, some 50 miles from the Uganda border. There seems to be little doubt of the heavy incidence of leprosy in this area, and perhaps this is not surprising for it borders the area in Uganda which has a very high incidence of the disease. From the number of admittances to the leprosy settlement at Kakamega it has been estimated that there cannot be less than 800 cases in this one district alone, and this may be an under-estimate, for the bordering Mbala district of Uganda has an incidence approaching 2 per cent. As in most places where leprosy is prevalent one finds little fear of the disease among the natives, and that the social and hygienic conditions of the population are bad. There is one leprosy settlement at Kakamega, with accommodation for over a hundred inmates. The great majority of these are unfortunately, very advanced cases. There appears, 
however, to be a general tendency for the earlier type of case to present itself for treatment, and as these begin to be discharged from the home, other, and still earlier cases will probably be attracted. The leprosy settlement itself consists of seventeen mud and wattle huts and a central corrugated iron roof hut, which is used as a store house. All treatment is carried out at the general hospital dispensary nearby, as there are no facilities at present for treatment in the settlement. Under present conditions, it is difficult to persuade patients to stay for a sufficiently long period. The Secretary in his report recommended that Kakamega should be developed further and form the central leprosy settlement for this area. If this were done, there would be a reasonable prospect of meeting the problem in North Kavirondo.

In Central Kavirondo leprosy work was started by Dr. Strangways Dixon at Maseno. After his departure cases were treated at the Government hospital. Out of 65,000 cases which presented themselves for treatment, 70 , or just over one per thousand, were cases of leprosy. It appears, therefore, that while the number of cases is not so great as in North Kavirondo, yet the amount of leprosy present is not negligible. The people of Central Kavirondo, however, have little if anything, to do with those of the North, and, therefore, they are averse to entering the leprosy camp at Kakamega. If this is so, and it is demonstrated that there are a large number of sufferers in the district, it might be well to consider the establishment of a small colony for the advanced and "open " cases of the district. Meanwhile, there are facilities for treatment at the government and mission hospitals.

In and around Nairobi there appears to be little leprosy. There are, however, about a dozen cases isolated in the infectious diseases hospital outside the city. Some thirty miles from Nairobi in the Kikuyu reserve the Scottish Mission are treating a few cases, and two wards have been erected with funds from the Association for isolating sufferers who may come for treatment. At Tumutumu and Chogoria in this reserve there seems to be a higher incidence, but, generally speaking, leprosy does not appear to be so prevalent as elsewhere.

(2) The Coastalbelt of Kenya seems to have a fair incidence, and it is at Msembwani, some 30 miles from the Tanganyika border on the coast and in the Diga district, that the Government have built a very good leprosy colony. At the time of the Secretary's visit the colony was close on completion; 
it is not known how many cases have been admitted since. In addition to the settlement at Msembwani there is one at Malindi which has been in existence for some years. It is proposed to continue this camp, for it is not always easy to persuade sufferers from leprosy to go outside their own tribal area for isolation. While leprosy is not so prevalent in Kenya as in certain other parts of Central Africa, yet it is by no means negligible and will demand the closest attention of the authorities before its ravages are in any way controlled.

\section{ZaNZIBAR.}

The protectorate of Zanzibar consists of two islands, viz., Zanzibar and Pemba. These islands are among the most beautiful and picturesque in all the African continent. It is cstimated that there are some 500 cases of leprosy in Zanzibar, and this gives an incidence of about one in six hundred. There is a settlement on Funzi Island, some four or five miles from Weti on the main island of Pemba. At the time of the Secretary's visit there were about 120 cases isolated, 50 of which were women. Unfortunately, the majority of cases which were seen were advanced, and without exception had the disease on an average of over three years before discovery, and, further, when the disease was discovered, were found to be in the later cutaneous stages. The work at Funzi is supervised by the Medical Officer from Weti, and two resident sisters carry on the routine work. In addition to the leprosy settlement, there is a colony for the old deformed arrested cases a few miles outside the town of Zanzibar. This is in charge of a Roman Catholic sisterhood, who look after the simple wants of the people. A few cases are also treated at the various dispensaries scattered throughout the Islands.

It is evident from recent investigations that leprosy occurs in localised foci. If this is the case, the disease should be more readily controlled. If contacts were examined regularly, as has been suggested should be done, it should be possible to trace 80 per cent. of new infections. As Sir Leonard Rogers, the Hon. Medical Adviser to the Association, has pointed out, in communities where such an examination could be enforced, it should be feasible to reduce the incidence of leprosy in ten years by 50 per cent. Zanzibar is a well ordered State, its people are above the average in intellect and civilisation ; therefore a scheme for the examination of contacts should be possible of enforcement. Recent information has come from the Government that such a 
plan is in contemplation. The outlook then, for the ultimate control of leprosy in Zanzibar should be good.

\section{TANGanyiKa.}

The Mandated Territory of Tanganyika, situated within the equatorial belt, is the home of most tropical diseases, and leprosy is no exception. The hot humid climate and the prevalence of malaria, dysentery, syphilis and sleeping sickness, all tend to lower the resistance of the people to such an extent that they fall ready victims to a chronic scourge such as leprosy. It has been stated that the incidence of leprosy averages about two per thousand, giving a total number of sufferers in Tanganyika of about 8,500, but as two per thousand is a very low estimate for the incidence of leprosy in Central Africa the actual number of sufferers may well be twice as high, or even higher. In the course of a hurried walk through a few villages in Northern Tanganyika, the writer noticed at least three cases in each village. The incidence of leprosy in India has been found to be vastly higher than it was ever thought to be, and there is no reason to think that the rough estimate given for the territories of Africa is any more accurate.

Within the last six years, a considerable amount of leprosy work has been organised in Tanganyika. The districts where definite work is being carried on are Moshi, Tanga, Shinyanga, Kilosa, Kilamatinde, Lindi and Songea. In Moshi there is a small Government camp which might well be developed further, for, while leprosy in this area is not as prevalent as elsewhere, yet from all accounts, it does not seem to be uncommon. In the Tanga district at Magila, Tongwe and Korogwe the U.M.C.A. are doing quite an extensive dispensary work, and as many as 100 cases are treated in some of their hospital out-patient departments. Perhaps the most extensive work is being done by Dr. Maynard at Shinyanga, a station on the railway line from Tabora to Mwanza. It seems that this, and the vast area along which runs the Central Tanganyika Railway, represents the heaviest foci of disease, for it is in these districts that quite a large amount of leprosy work has been developed. C.M.S. at Kilamatinde and at Berega (Kilosa district) are also developing leprosy settlements for the treatment of the numerous cases around their mission stations. Further south, there seem to be two fairly large foci, one some 30 miles inland from Lindi, and another in the Songea district. The U.M.C.A. are carrying on work in the Masasi Diocese of the former district and a 
Roman Catholic mission have work near Lindi and the same mission have also developed a leprosy settlement in the Songea area at Peramiho.

The Secretary on his East African visit was unable to see much of the work, but there seems little doubt that leprosy is one of the major problems of Tanganyika, and the Government have been urged to appoint a special officer for leprosy investigation purposes. Unfortunately, owing to shortage of funds, little can be done in this direction. Here is an opportunity for some philanthropist to help in a practical manner to relieve this open sore of Central Africa, for little permanent work can be done without a specialist investigating, surveying, and constantly working out plans to deal with the problem. This scourge is not insoluble and given right methods leprosy is a preventible disease. 